\title{
Psychometric properties of Compulsive Internet Use Scale (CIUS): A systematic review and meta-analysis
}

\author{
Zorunlu internet Kullanim Ölçeğinin (CIUS) psikometrik özellikleri: Sistematik \\ bir inceleme ve meta-analiz çalışması \\ Masumeh Ghazanfarpour1, Hossein Dabiriyan Tehrani2 ${ }^{2}$ Nasrin Khajeali3 ${ }^{3}$ Abbas Keshtkar4, \\ Masoudeh Babakhanian ${ }^{5}$ \\ ${ }_{1}$ Phd, Student Research Committee, Kerman University of Medical Sciences, Kerman, Iran https: //orcid.org/0000-0003-4639-3711 \\ 2Phd, Allameh Tabatabaei University, Tehran, Iran https://orcid.org/0000-0002-0802-0810 \\ 3 Phd, Medical education, Ahvaz Jundishapour University of Medical Sciences, Ahvaz, Iran https: //orcid.org/0000-0003-4929-812X \\ ${ }^{4}$ Phd, Tehran University of Medical Sciences, Tehran, Iran https: //orcid.org/0000-0002-7305-8639 \\ 5 Phd, Student Research Committee. Psychiatry and Behavioral Research Centre. Addiction Institute. Mazandaran University of Medical \\ Sciences, Sari, Mazandaran, Iran. https: //orcid.org/0000-0002-6128-8023
}

\section{SUMMARY}

Objective: This article performs a systemic review of psychometric properties and factor structure of the Compulsive Internet Use Scale (CIUS), the scale for assessing Internet addiction behavior in clinics and research fields. Method: Studies measuring psychometric properties and factor structure of CIUS (original version) were searched through MEDLINE in PubMed, SCOPUS, Pub Psych, google scholar and SID \& Iran medex (Iranian database). A total of 18 studies (24 samples) including 44,198subjects were reviewed in our study. Results: Based on meta-analysis for internal consistency, the pooled Cronbach's alpha coefficient from all study was 0.47(95percent confidence interval [Cl], 0.46-0.49). Based on meta-analysis for internal consistency adolescence subgroup was 0.48 (95percent confidence interval $[\mathrm{Cl}], 0.45-0.51)$, and addicted to behavior addiction subgroup was 0.48 (95 percent $\mathrm{Cl}, 0.44-0.51$ ), in general population subgroup was 0.47 (95percent confidence interval $[\mathrm{Cl}], 0.42-0.53)$, in university student subgroup was 0.47 (95percent confidence interval [Cl], 0.43-0.51), in internet user was 0.45 (95percent confidence interval $[\mathrm{Cl}], 0.43-0.47)$, by cultural of country for collectivistic society was 0.49 (95percent confidence interval [Cl], 0.46-0.52), and individualistic societies was 0.46 (95 percent confidence interval $[\mathrm{Cl}], 0.44-0.47)$ and based quality assessment subgroup for study was 0.47 (95percent confidence interval $[\mathrm{Cl}], 0.46-0.49)$. Discussion: Future studies should be conducted on the multiethnic population and cross-cultural designee. Future studies should be developed and reported based on the COSMIN checklist.

Key Words: Compulsive Internet Use Scale, psychometric, reliability, validity, systematic review, meta-analysis

\section{ÖZET}

Amaç: Bu makalede, kliniklerde ve araştırma alanlarında internet bağımlıı̆̆ı davranışını değerlendirmek için bir ölçek olan Zorunlu İnternet Kullanım Ölçeğinin psikometrik özelliklerinin ve faktör yapısının sistematik bir incelemesi yapılmıştır. Yöntem: Bu çalışmalar CIUS'nin yapısal faktörlerinin psikometrik özelliklerini ölçmektedir. MEDLINE in PubMed, SCOPUSE, Pub Psych, google scholar, SID ve Iranmedex'te (İran veritabanı) arama motorları kullanıldı. Bu çalışmada toplam 18 makale (24 örnek) incelenmiştir. Bulgular: Tüm çalışmalarda Cronbach Alfa meta analizinin sonuçları 0.47 idi (\% 95 güven aralığı 0.46-0.49). Farklı alt gruplarda Cronbach alfa meta analizinin değeri aşağıdaki gibidir: gençler alt grubunda 0.48 (\% 95 güven aralığı 0.45-0.51), üniversite öğrencileri alt grubunda 0.47 (\% 95 güven aralığı 0.43-0.51) davranış bağımlıları alt grubunda 0.48 (\% 95 güven aralığı 0.44-0.51) Genel popülasyon alt grubunda 0.47 (\% 95 güven aralığı 0.420.53), internet kullanıcılarında 0.45 (\% 95 güven aralığı 0.43-0.47), kolektivist sosyal kültür olarak sınıflandırılan ülkeler için 0.49 (\% 95 güven aralığı 0,46-0,52) ve bireyci sosyal kültürü olan ülkelerde 0,46 (\% 95 güven aralığı $0,44-0,47)$, çalışmaların nitel değerlendirmesine göre $0,47$ (\% 95 güven aralığı $0,46-0,49)$ idi. Sonuç: Gelecekteki çalışmalar çok etnikli ve kültürlerarası topluluklar üzerinde tasarlanıp uygulanmalıdır ve ayrıca faaliyetlerini standart COSMIN kontrol listesine göre tasarlayıp uygulamalıdır.

Anahtar Sözcükler: Geçerlilik, güvenilirlik, sistematik inceleme, meta-analiz

(Turkish J Clinical Psychiatry 2020;23:352-363)

DOI: $10.5505 / k p d .2020 .81489$ 


\section{INTRODUCTION}

Due to technological advances and increased access to information technology, in the past two decades, internet addiction has been a growing phenomenon that has become a global concern (1). It includes addiction to social media, digital entertainment, video games, pornography, shopping, and texting $(2,3)$. Since this disorder is still unknown, it is not mentioned in the Diagnostic and Statistical Manual of Mental Disorders (DSM5)(2); however, the recent findings suggest that it should be included (3). The internet users show symptoms similar to drug users such as spending excessive time in conducting the behavior, repeated and unsuccessful attempts to control or stop that behavior, having low control over behavior, and mental and social deprivation and retardation (4). This disorder leads to serious harms such as lack of exercise, inappropriate nutrition, smoking, highrisk behaviors, and occupational, educational, and social harms (5).

The first internet addiction assessment tools were created in the mid-1990s, according to clinical gambling and drug addiction definitions in DSM; all included many questions about this type of behavioral addiction (6-8). However, Meerkerk et al. (2009) developed a tool to assess the intensity of compulsory use of the internet in the Netherlands which showed a good psychometric property among the general population; it included 14 items and 1 factor (9). This tool included tolerance, withdrawal symptoms, loss of control, preoccupation, conflict, coping, and lying about involvement; these are drug addiction symptoms in the fourth edition of diagnosis and statistical guide to psychiatric disorders and pathological gambling addiction as well as Griffiths benchmark for behavioral addiction (9). This tool is shorter than other similar tools and its use is more convenient in online surveys (9).

After creating this tool, its psychometric properties were investigated in different cultures and languages in different countries on various population groups such as internet users, gamblers, students, etc. However, this study aimed to investigate the factor structure and validity and reliability of the CIUS scale in all existing versions based on contro- versial findings for the structure of this tool in different groups.

\section{METHOD}

\section{Aim of the study}

The psychometric properties and validation of the "compulsive Internet use scale" questionnaire have recently gained the attention of researchers. Recent studies have found the psychometric properties of this scale in some user groups, cultures and populations. "compulsive Internet use scale" is a diagnostic instrument and has validity and reliability for both healthy and clinical groups in children and adults.

So, we conducted a review study to investigate the reliability and validity of CIUS, since its emergence The goal of this study is to investigate the factor structure, the validity, and reliability of the "CIUS" scale about the inconsistent constructs captured by this scale among different populations. Moreover, CIUS scores of individuals in different groups of people investigated. (for example, people with internet addiction; people with gambling disorders, healthy people and ....)

\section{Research questions}

1. Does the CIUS have adequate evidence of reliability and validity?

2. Reviewing the psychometric properties of the Compulsive Internet Use Scale (CIUS) Considering the quality of study in different samples and places around the world.

The link of the registered protocol in the research gate is available on https://www.researchgate.net/publication/33231877 8_Structural_factors_of_Compulsive_Internet_Us e_Scale_CIUS_In_healthy_and_clinical_populations_a_systematic_review.

To this end, we reported the Meta-analysis of coefficient alpha, risk of bias of These studies, 
Sensitivity analysis and publication bias and results of fit indices (for e.g.; $\mathrm{X}^{2}$, df, CFI, GFI, TLI, RMSEA) for each of these studies, as well as, cutoff point, validity, and reliability.

Searches: We search in electronic bibliographic databases like MEDLINE in PubMed, SCOPUS, Pub Psych, google scholar and SID \& Iranmedex (Iranian database) for this study. Also, other databases reviewed (for gray literature ) [e.g, conference paper, key journal, ...]. The search strategy used the keywords of (Compulsive Internet Use Scale or CIUS) AND (Reliability OR validity OR Psychometrics OR Factor Analysis OR exploratory factor analysis OR confirmatory factor analysis OR CFA OR EFA OR Cronbach's alpha OR TestRetest Reliability). In our review, there was no language or date restriction. We also checked the bibliographies of related articles to detect any studies not retrieved via the above mentioned electronic databases.

Start date of searching electronic databases until the $01 / 01 / 2018$ date of searching.

\section{Participants/population}

All patients with psychological disorders and healthy groups of different ages and both genders included.

Papers in which CIUS is used as a scale in data collection and their results included.

\section{Inclusion criteria}

(a) Studies are needed to assess the factor structure of the CIUS using confirmatory factor analysis.

(b) the appropriate fit indices (e.g. $\mathrm{X}^{2}, \mathrm{CFI}$, GFI, TLI, SRMR, RMSEA) for tested models should be reported in the studies.

(c) Studies should be full text, peer-reviewed and written in English or any other languages.

Exclusion criteria: studies without adequate quality after assessment and study that used the short form of CIUS.

Intervention(s), exposure(s): This review study does not focus on a specific intervention.

Main outcome(s): CIUS is a short and easy instrument that has recently caught the interest of researchers and practitioners. Up to now, several psychometric validations of CIUS have been carried out in different languages and cultures. in this study, we gathered the internal consistency, Factorstructure, reliability, factor structure and validity of the CIUS.

\section{Data extraction (selection and coding)}

After evaluation of included data using COSMIN tool (10), we used a standardized form in excel for the following information extracted from each paper:

- Primary information: authors, title, year of publication, language, place

- Study characteristics: country, sample size, participants, intervention details like type and number of groups

- Participants: age, gender, target group

- Outcomes: Measurement properties (a type of results)

Two authors independently extracted data from the included studies. Disagreements resolved by discussion.

To assess cultural differences concerning this scale, the current project incorporated each country's score on collectivism versus individualism, per Hofstede's cultural values framework (11). The Hofstede definition of a highly collectivistic society leans toward "a tightly-knit social framework". On the contrary, individualistic societies refer to "a loosely-knit social framework" (11). 
Risk of bias (quality) assessment: To assess the risk of bias for each of the included studies, each item assigned "low-risk bias" score when the data of the study was completed, "moderate" score when the data was incomplete and "high-risk bias" when the data was missing.

Strategy for data synthesis: Although different approaches of meta-analyzing reliability results have been introduced, we relied on the method outlined by Rodriguez and Maeda (12) for Cronbach's alpha. This method based on a transformation of Cronbach's alpha as the effect $\operatorname{size}(13)$.

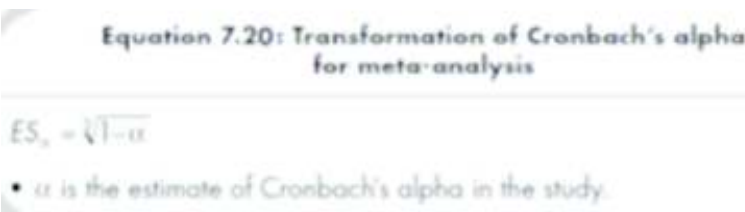

The standard error of the transformed internal consistency relies on a function of the number of items on the scale employed in the investigation, the amount of sample size, and the estimation of internal consistency itself (12)

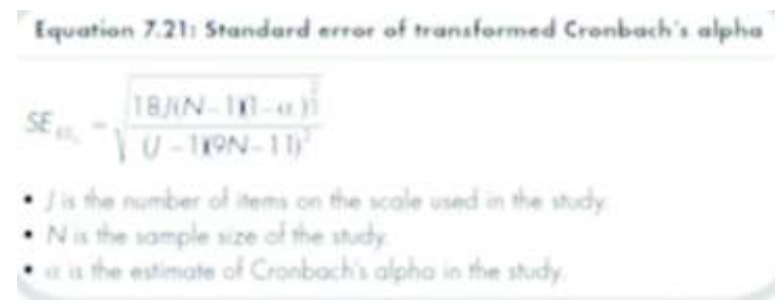

Following computing the pooled transformed internal consistency (and confidence interval limits or predicted values at various levels of moderators), the back-transform were applied to the more interpretable Cronbach's alpha (13):

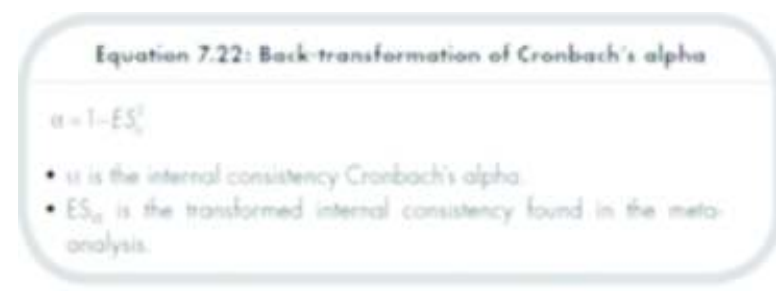

The decision to apply the random-effects model was derived from our interpretation of whether or not most primary studies included shared the same methodology. Because there exist varieties and dif- ferences in methodology (methodological heterogeneity), the random effect model was applied. All analyses were carried out using Stata V.13 software (Stata Corp LP, College Station, Texas, USA) through a personal laptop.

Assessment of heterogeneity: Heterogeneity among included studies was assessed by the p-value of the Q Cochrane test and I2 statistic, which estimates the proportion of variability in the meta-analysis caused by differences between studies(14). Per the Cochrane guidelines, the degree of heterogeneity was interpreted as follows: (a) 0-40 percent: not significant; (b) 30-60 percent: moderate; (c) 50-90 percent: substantial; and (d) 75-100 percent: considerable(15). Inconsistency was examined by subgroup analysis. The factors exerting an influence on the variation of effect size were also assessed by meta-regression.

Publication bias and sensitive analysis: To address possible small study effects, "funnel plot," "Egger's test and test of Begg," and "Fill and trim method" were applied. The performing of sensitivity analysis was applied to deal with the robustness of systematic review outcomes. In this regard, the visual representation of sensitive jackknife was conducted to recognize the primary research showed the highest change from pooled EFFECT SIZE. Different items also address the essential sources of these changes.

Risk of Bias assessment: We used the COSMIN Risk of Bias checklist for systematic reviews for judgment of risk of bias(General design, Reliability, Internal structure, and Structural validity) in this study(16).

Funding: This study was partly supported by Grant Number 19, Ethic code IR.MAZUMS.REC.1398.019 and Approval Date: 2019-02-20 from the Mazandaran University Of Medical Sciences.

\section{RESULTS}

Included study: During the advanced search,1170 primary studies were identified. After Eliminated 
Psychometric properties of Compulsive Internet Use Scale (CIUS): A systematic review and meta-analysis

Table-1. The COSMIN checklist for methodological quality of studies

\begin{tabular}{|c|c|c|c|c|c|c|c|}
\hline Authors. Reference & 1 & 2 & 3 & 4 & 5 & 6 & Quality assessment \\
\hline Meerkerk et al.,(9) & High & low & high & high & high & low & high \\
\hline Alavi et al..(17) & Low & low & high & high & low & high & Moderate \\
\hline Downing et al.,(18) & High & high & high & high & low & low & High \\
\hline Wartberg et al..(19) & High & high & high & high & high & low & High \\
\hline Guertler et al.,(20) & high & high & low & low & high & low & moderate \\
\hline Guertler et al.,(21) & Low & high & high & low & low & high & moderate \\
\hline Peukert et al..(22) & High & low & low & low & low & low & low \\
\hline Dhir A et al...(23) & Low & high & high & low & high & high & high \\
\hline Dhir A et al...(24) & Low & high & high & low & high & high & high \\
\hline Khazaal Y et al..(25) & high & low & low & high & high & low & moderate \\
\hline Khazaal Y et al..(26) & High & high & low & high & high & low & high \\
\hline Kuzucu Y et al...(27) & High & low & high & high & high & high & high \\
\hline Silva Sales A et al..(28) & High & low & high & high & high & low & high \\
\hline Roseline YK-F et al.,(29) & Low & low & high & high & high & high & high \\
\hline Bteich G et al...(30) & High & low & high & low & low & low & low \\
\hline Chaillot EC et al..(31) & High & low & high & high & low & low & moderate \\
\hline Barke $\mathrm{A}$ et al..(32) & Low & high & high & high & high & high & high \\
\hline Jacqueline M et al(33).. & High & high & high & high & high & high & high \\
\hline $\begin{array}{ll}1- & \text { Do the scales hav } \\
2- & \text { Was the percenta } \\
3- & \text { Was there adequ } \\
4- & \text { Was there adequ } \\
5- & \text { Was exploratory } \\
6- & \text { Were test- retest }\end{array}$ & $\begin{array}{l}\text { effect } \\
\text { e of } \mathrm{mi} \\
\text { y for } \mathrm{t} \\
\text { y for } \mathrm{t} \\
\mathrm{i} \text { confi. } \\
\text { carried }\end{array}$ & $\begin{array}{l}\text { licator } \\
\text { ng iter } \\
\text { sampl } \\
\text { sampl } \\
\text { atory } \mathrm{f} \\
\text { ? }\end{array}$ & $\begin{array}{l}\text { re mea } \\
\text { resen } \\
\text { e in tl } \\
\text { e in tl }\end{array}$ & $\begin{array}{l}\text { Aalysis } \\
\text { ternal } \\
\text { carrie }\end{array}$ & $\begin{array}{l}\text { asten } \\
\text { ut for }\end{array}$ & $\begin{array}{l}\text { malysi } \\
\text { sical }\end{array}$ & st Theory (CTT)? \\
\hline
\end{tabular}

studies, after limiting search, non-relevant article, duplicate, screened by title and abstract, screening the full text, Finally, 19 articles were considered eligible for meta-analysis (Figure 1).

Quality of study: After the evaluation of included data using the COSMIN tool (10), involving internal consistency, reliability, content validity, structure validity, and construct validity. Within this checklist, measured aspects of construct validity and internal consistency assessed using 6 questions (Table1).

Study characteristics: A total of 18 studies (24 samples) were included in the qualitative systemat- ic review (Table 2). The included articles were published between 2009 and 2018. In total, 44,198subjects were identified among 18 studies.

General characteristics of included studies for meta-analysis: 18 studies(24 samles) tested for internal consistency, quality assessment and subgrouping by cultural countries. seven for the adolescence target group, 5 for the addicted to the behavioral target group, 4 for the general population target group, 6for university student target group and 2 for internet user target group(see fig $2,3,4,5)$.

Sensitivity analysis and publication bias: The per-

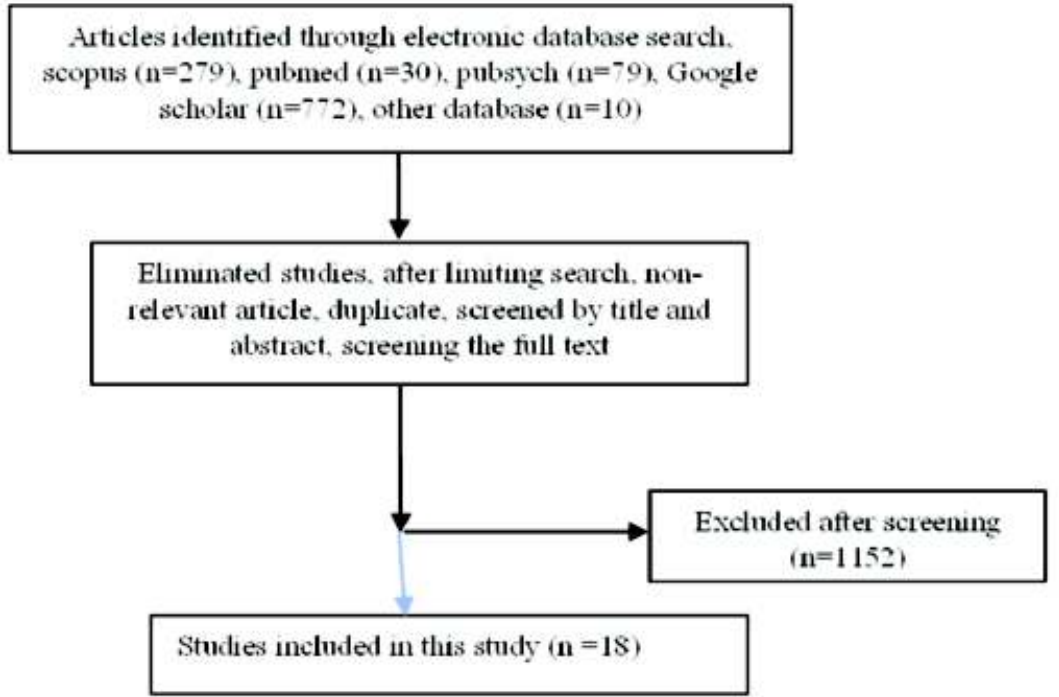

Figure 1. PRISMA flowchart for selection of primary studies 
Table 2. The characteristic of studies included in - systematic review and meta-analysis

\begin{tabular}{|c|c|c|c|c|c|c|c|}
\hline & $\begin{array}{l}\text { Authors, } \\
\text { Year. } \\
\text { Reference }\end{array}$ & Version & $\begin{array}{l}\text { Target } \\
\text { group }\end{array}$ & Age & Sample size & $\begin{array}{l}\text { Internal } \\
\text { consiste } \\
\text { ncy } \\
\text { (alpha) } \\
\end{array}$ & $\begin{array}{l}\text { Main Results(number of factor and } \\
\text { item. Score of CrUS, results of EFA } \\
\text { and CFA and Reliability) }\end{array}$ \\
\hline \multirow[t]{3}{*}{1} & \multirow[t]{3}{*}{$\begin{array}{l}\text { Meerkerk et } \\
\text { al.2009.(9) }\end{array}$} & \multirow[t]{3}{*}{ Dutch } & $\begin{array}{l}\text { Studyl- } \\
\text { heavy } \\
\text { Internet } \\
\text { users }\end{array}$ & $38.5 \pm 12.5$ & $\begin{array}{l}447(226 \text { female } \\
\text { and } 227 \text { Male })\end{array}$ & 0.89 & $\begin{array}{l}\text { This scale has } 1 \text { factor and } 14 \text { items on } \\
\text { a } 5 \text {-point Likert scale. } \\
\text { standardized factor loadings between } \\
0.48 \text { and } 0.69 \text {. good fit: RMSEA :0.054 } \\
\text { and CFF:0.98, X }: 160.3 \text {. df } 72 \text {. }\end{array}$ \\
\hline & & & $\begin{array}{l}\text { Study2- } \\
\text { heavy } \\
\text { Internet } \\
\text { users }\end{array}$ & $15-18$ & 229 & 0.89 & $\begin{array}{l}\text { This scale has } 1 \text { factor and } 14 \text { items on } \\
\text { a } 5 \text {-point Likert scale. The factor } \\
\text { loadings were between } 0.45 \text { and } 0.70 \text {. } \\
\text { Confirmatory factor analysis on the } 14 \\
\text { items with one factor and including the } \\
\text { five correlated error terms. RMSEA } \\
: 0.053 \text { and CFI:0.96, } \mathrm{X}^{2}: 208.5, \mathrm{df}: 72 \text {. }\end{array}$ \\
\hline & & & $\begin{array}{l}\text { Study3- } \\
\text { regular } \\
\text { Internet } \\
\text { users }\end{array}$ & $25.3 \pm 10$ & $\begin{array}{l}16925(13100 \\
\text { Male and } 3825 \\
\text { Female) }\end{array}$ & 0.90 & $\begin{array}{l}\text { This scale has } 1 \text { factor and } 14 \text { items on } \\
\text { a 5-point Likert scale. Factor loadings } \\
\text { ranging from } 0.54 \text { to } 0.73 \text { and good fit: } \\
\text { RMSEA :0.054 and CFI:0.98, } \mathrm{X}^{2} \text { : } \\
3497.0 \text {. df } 72 \text {. }\end{array}$ \\
\hline 2 & $\begin{array}{l}\text { Alavi et } \\
\text { al.2011.(17) }\end{array}$ & Iranian & $\begin{array}{l}\text { university } \\
\text { student }\end{array}$ & $22.9 \pm 4.05$ & $\begin{array}{l}400(287 \text { Male } \\
\text { and } 113 \\
\text { women) }\end{array}$ & 0.89 & reliability or test-retest $(\mathrm{r}=0.83)$ \\
\hline 3 & $\begin{array}{l}\text { Downing et } \\
\text { al.2014.(18) }\end{array}$ & $\begin{array}{l}\text { New } \\
\text { York }\end{array}$ & $\begin{array}{l}\text { man on man } \\
\text { pomograph } \\
\text { y use }\end{array}$ & $32.9 \pm 12.5$ & 265 Male & 0.92 & $\begin{array}{l}\text { A principal components analysis } \\
\text { revealed a single-component and } 13 \text { - } \\
\text { item and explained } 52.45 \% \text { of the } \\
\text { variance. }\end{array}$ \\
\hline 4 & $\begin{array}{l}\text { Wartberg et } \\
\text { al.2014.(19) }\end{array}$ & German & juvenile & $15.5 \pm 1.12$ & $\begin{array}{l}1723(50 \% \text { Male } \\
\text { and } \\
87250 \% \text { Female })\end{array}$ & 0.92 & $\begin{array}{l}\text { The First model was rejected and in the } \\
\text { second model, the Fit indices: } 516.78 \text {, } \\
\text { The values for the RMSEA } \\
(0.060) \text {, the SRMR }(0.032) \text {, the CFI } \\
(0.968) \text {, and TLI }(0.959), \mathrm{X}^{2}: 0.060 \text {. } \\
\text { df: } 72\end{array}$ \\
\hline 5 & $\begin{array}{l}\text { Guentler et } \\
\text { al.2014.(20) }\end{array}$ & German & student & $\begin{array}{l}35.24 \pm 13 \\
79\end{array}$ & $\begin{array}{l}8132(4.155 \mathrm{Male} \\
\text { and } \\
3.977 \mathrm{Female})\end{array}$ & 0.89 & $\begin{array}{l}\text { one } \\
\text { factor and five conrelated errors. } \\
\text { RMSEA } \\
(0.027) \text {, the SRMR }(0.029) \text {, the CFI } \\
(0.966) \text {, and AIC }(268.123) . \mathrm{X}^{2}: 485 \text {. } \\
\text { df: } 72 \text {. mean CIUS score was } 8.84(\mathrm{SD}= \\
7.46) \text { and a range of } 0-52 \text {. }\end{array}$ \\
\hline 6 & $\begin{array}{l}\text { Guentler et } \\
\text { al.2014.(21) }\end{array}$ & German & Gamblers & $\begin{array}{l}35.28=11 . \\
93\end{array}$ & $\begin{array}{l}292 \text { (237Male } \\
\text { and 55Women) }\end{array}$ & 0.90 & $\begin{array}{l}\text { cut-off } \geq 18 \text { (sensitivity } 79.7 \% \text {, } \\
\text { specificity } 79.4 \% \text { ). }\end{array}$ \\
\hline 7 & $\begin{array}{l}\text { Peukert et } \\
\text { al.2012.(22) }\end{array}$ & German & $\begin{array}{l}\text { university } \\
\text { student }\end{array}$ & $\begin{array}{l}18- \\
54 \text { years }\end{array}$ & 2506 & 0.93 & $\begin{array}{l}\text { Confirmatory factor analysis showed } \\
\text { single factor, Error correlations: Items } \\
1-2,6-7,8-9,10-11,12-13 \text {. }\end{array}$ \\
\hline \multirow[t]{2}{*}{8} & \multirow[t]{2}{*}{$\begin{array}{l}\text { Dhir A et } \\
\text { al.2015.(23) }\end{array}$} & \multirow[t]{2}{*}{ Indian } & $\begin{array}{l}\text { Study A: } \\
\text { adolescent } \\
\text { Internet } \\
\text { users }\end{array}$ & $33.5 \pm 10.2$ & $\begin{array}{l}\text { 2383(1412Male, } \\
\text { 950Female) }\end{array}$ & 0.87 & $\begin{array}{l}\text { Mean CIUS score was } 33.5 \pm 10.2 \text {, one- } \\
\text { factor solution for the } 14 \text {-item } \\
\text { CIUS. Variance explained for Factor } 1 \\
: 38.06 \% \text { and for Factor } 2: 10.39 \% \text {. Fit } \\
\text { indices for Model A: } \\
\text { x } 2 \text { df }(10.61) \text {,CFI:(0.86). GFI:( } 0.90) \text {, } \\
\text { TLI:(0.84).RMSEA:(0.09) AND for } \\
\text { Model B : x } 2 / \text { df:(4.37),CFI:(0.95), } \\
\text { GFI:(0.96). TLL:(0.94).RMSEA:(0.05). }\end{array}$ \\
\hline & & & $\begin{array}{l}\text { Study B- } \\
\text { adolescents }\end{array}$ & $\begin{array}{l}14.67 \pm 3.4 \\
4\end{array}$ & $\begin{array}{l}\text { 1036(592Male, } \\
\text { 399Female) }\end{array}$ & 0.86 & $\begin{array}{l}\text { Mean CIUS score was } 27.32 \pm 9.13 \text {, one- } \\
\text { factor solution for the } 14 \text {-item } \\
\text { CIUS. Variance explained for Factor } 1 \\
: 38.06 \% \text { and for Factor } 2: 10.39 \% \text {. Fit } \\
\text { indices for Model A: } \\
\text { x } 2 \text { df }(8.18) \text {.CFI:(0.88), GFI: }(0.92) \text {, } \\
\text { TLI }(0.86) \text {.RMSEA:(0.08) AND for } \\
\text { Model B : x2 df:(3.62),CFI: }(0.96) \text {. }\end{array}$ \\
\hline
\end{tabular}


continued Table 2. The characteristic of studies included in - systematic review and meta-analysis

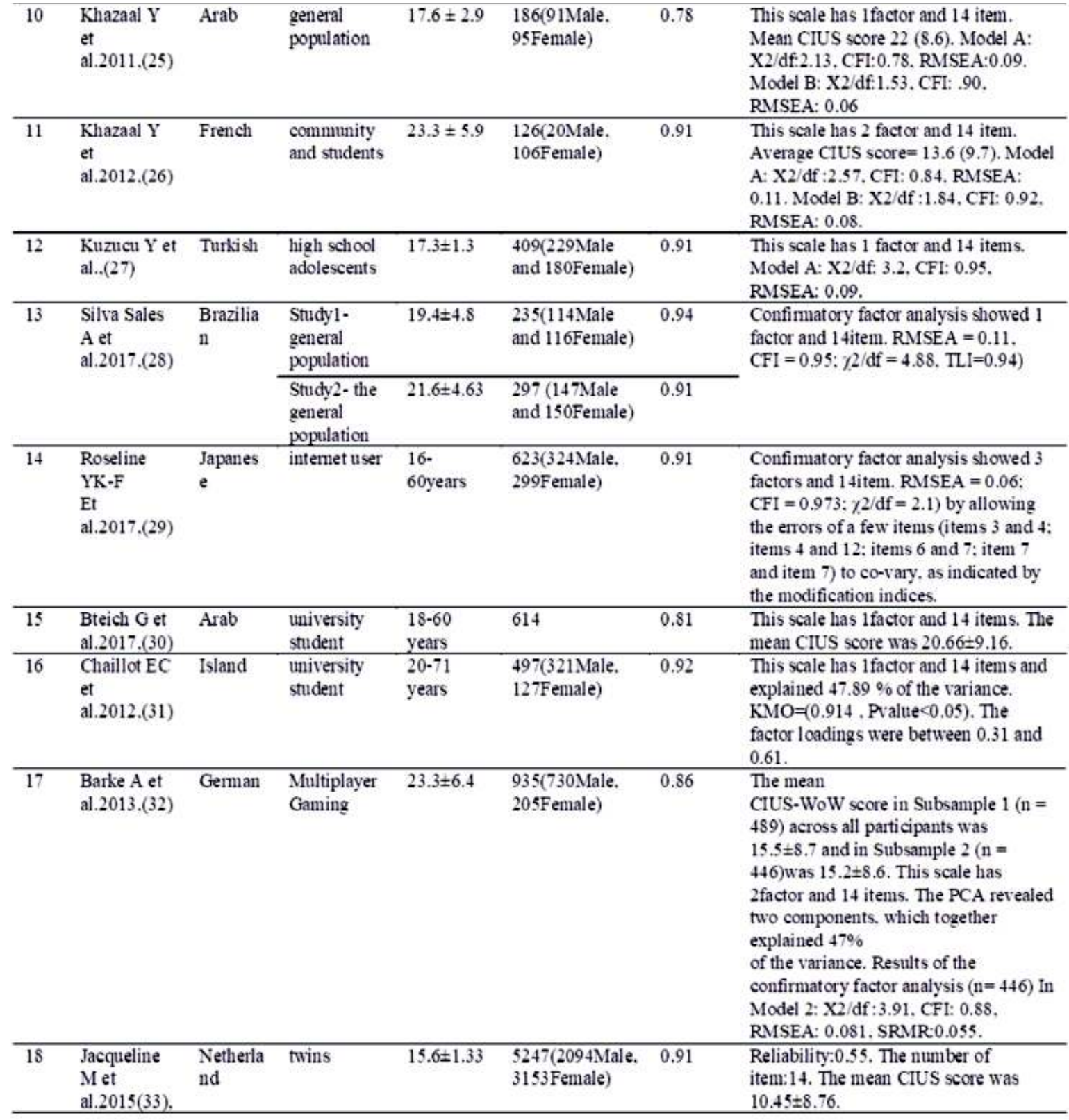

forming of sensitive jackknife reports that before carrying out one out method, the pooled effect size is $0.894,95 \%$ CI [0.885, 0.903]. The visual representation of sensitive analysis displays that the nearly most primary studies are located surrounding the overall effect size. However, removing the studies of 9 and 20 show the greatest changes.

To assess publication bias, the visual representation of the funnel plot illustrates that the pattern of data concerning effect size is homogeneous. In this sense, the publication bias is perceived to be igno- rable (see Figure 6).

The non-significant results for the Begg test $(z=$ $.92, p=0.35$ ) bear wittiness to the fact that the publication biases are ignorable.

The coefficient of bias and p-value in the Egger test are equated to $-1.644(\mathrm{p}=0.56)$. Similar to the Begg test, publication bias is assumed to be ignorable.

Conducting the trim and fill method shows that two studies were added. According to the overlapping 


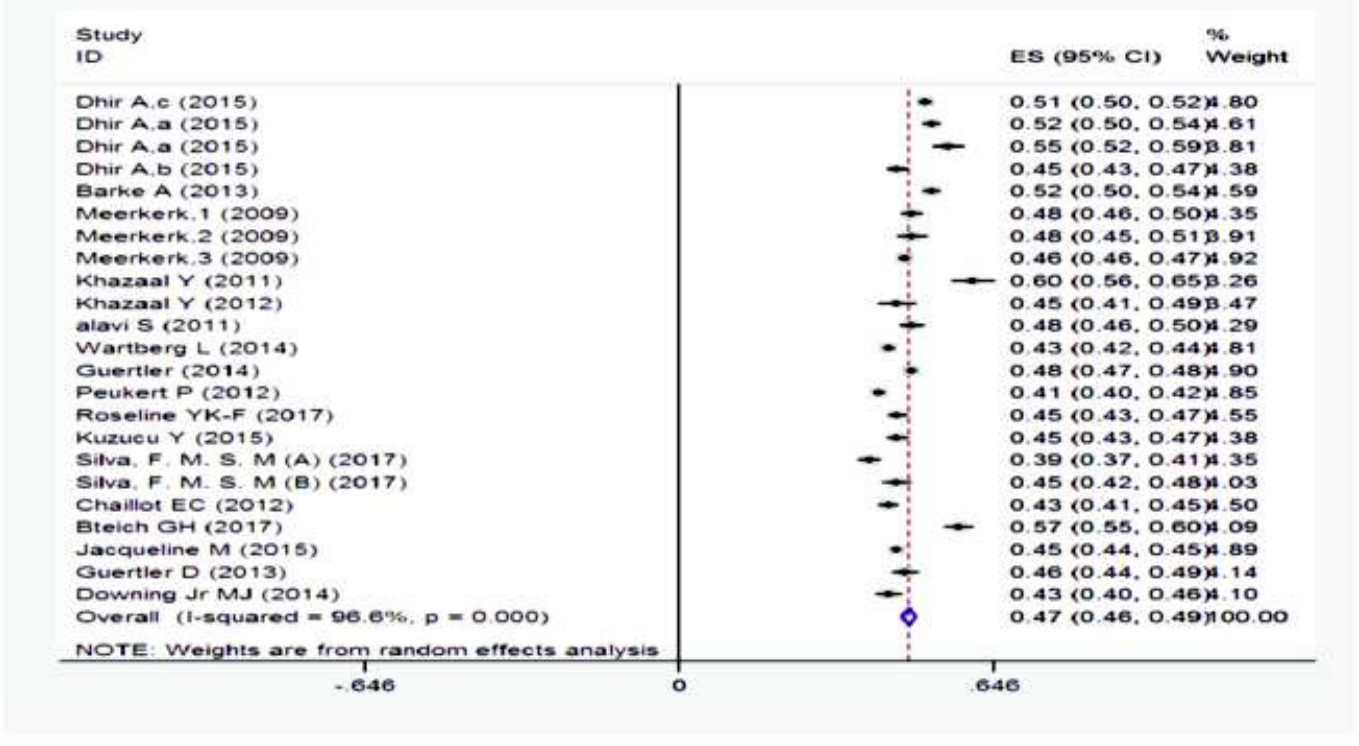

Figure 2. Forest plot of Cronbach's a for all studies

between their confidence intervals, it could be argued that no-considerable difference was detected between the result of the overall effect size of this study and the trim and fill method. Likewise, the P-value in the estimated random model is $(p<0.001)$. The significant $p$-value is indicative of the fact that the findings of this study are hardly altered by the modification of publication bias. This fact, in turn, suggests that publication bias, in this study, believe to be ignorable.

\section{DISCUSSION}

As far as I know, this is the first systematic review and meta-analysis were conducted to Psychometric Properties of Compulsive Internet Use Scale (CIUS).

Many variables affect the heterogeneity level in subgroups. The location of distributing questionnaires, time, sampling method, demographic characteristics of subjects, and common errors in standardizing CIUS questionnaire may cause heterogeneity in findings; the small sample size may also cause bias. However, the "risk of bias assessment" section helps to determine the generalizability of studies.

The researchers can employ the Item Response Theory (IRT) to deeply evaluate the psychometric properties of the items, thereby predisposing a higher sense of confidence to include only key items in the tool.

Moreover, the classic test theory (CTT) was utilized for our analyses. However, the assumption of not related to errors in classical test theory may not hold in every case, e.g. when common valuation methods, reversed or worded test items too, social desirability, or overlapping details of items are ready(34). Therefore, the Item Response Theory model should be administered to finalize the questionnaire for obtaining accurate data using a larger sample of $>1000$. The approving can be known by longitudinal data. It will be very beneficial for Clients to evaluate for psychiatric disorders because the cases refer to outpatient clinic with various emotional and behavioral problems (35). Both the research and the clinic can profit from valid and reliable tools in the future but still wanted to unravel basic mechanisms and consequences.

\section{Limitations and suggestions for future}

The bias selection could influence our data because of the purposive sampling method that was used for the random sampling method, which means limiting probably the generalizability of our results. One of the main limitations of the meta-analysis is high Heterogeneity among subgroups and groups. However, sensitivity analysis, subgroup analysis, and Meta-regression were conducted to detect potential resources of high heterogeneity. 


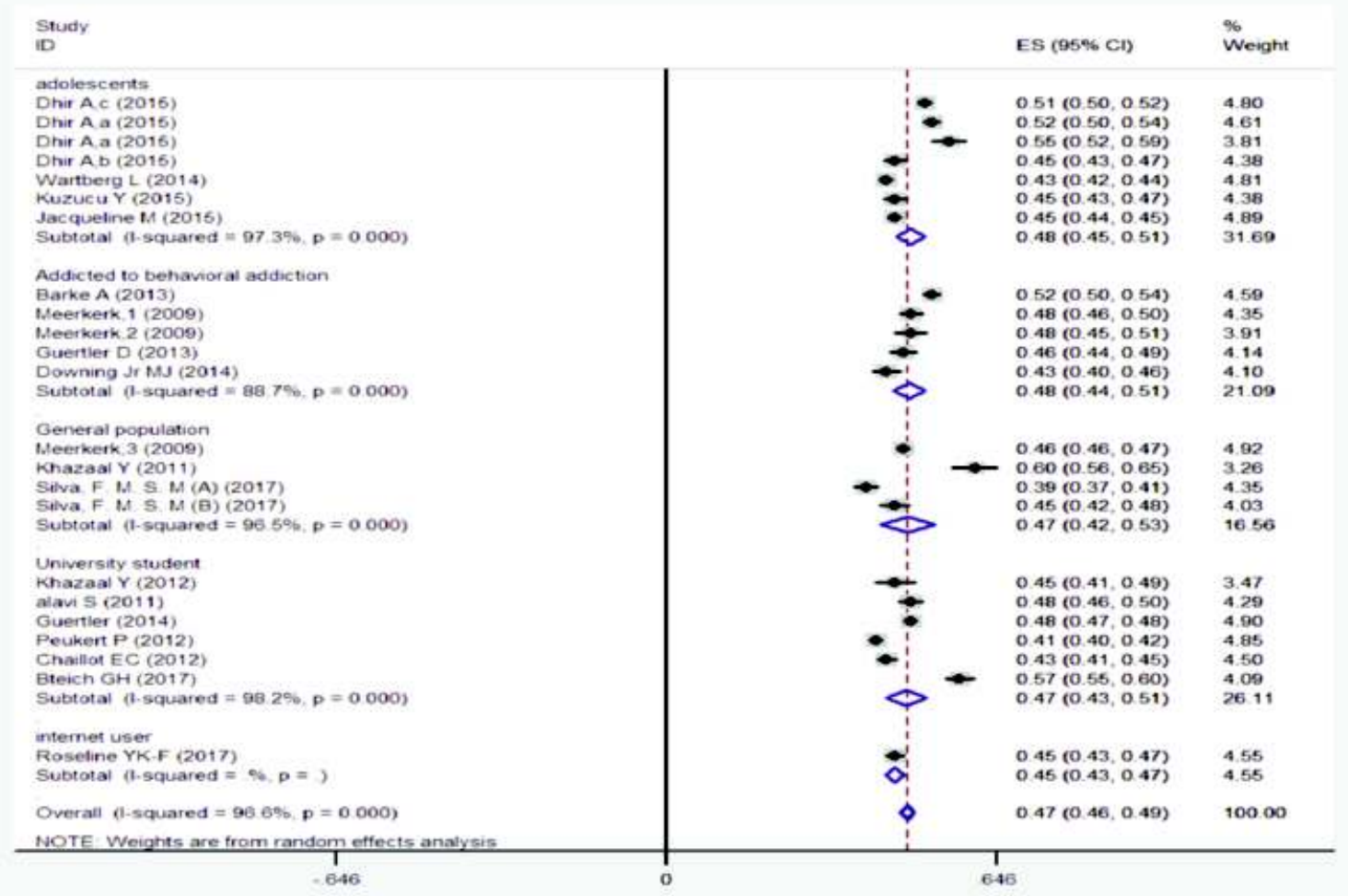

Figure 3. Forest plot of Cronbach's a for all subgroups

Subgroup analysis was undertake based on the culture of countries, quality of studies, population study (adolescents, addicted to behavior addiction, general population, university student). However, subgroup analysis and Meta-regression were unable to detect the reason for high heterogeneity. The performing of sensitive jackknife showed that removing the studies of 9 and 20 show the greatest changes. Further qualitative research is needed to design to detect high heterogeneity.

Moreover, The short version of this tool was not included in the analysis. It is recommended to study them too.

Limitation of the Meta-analysis is that several methods were conducted to calculate whether the

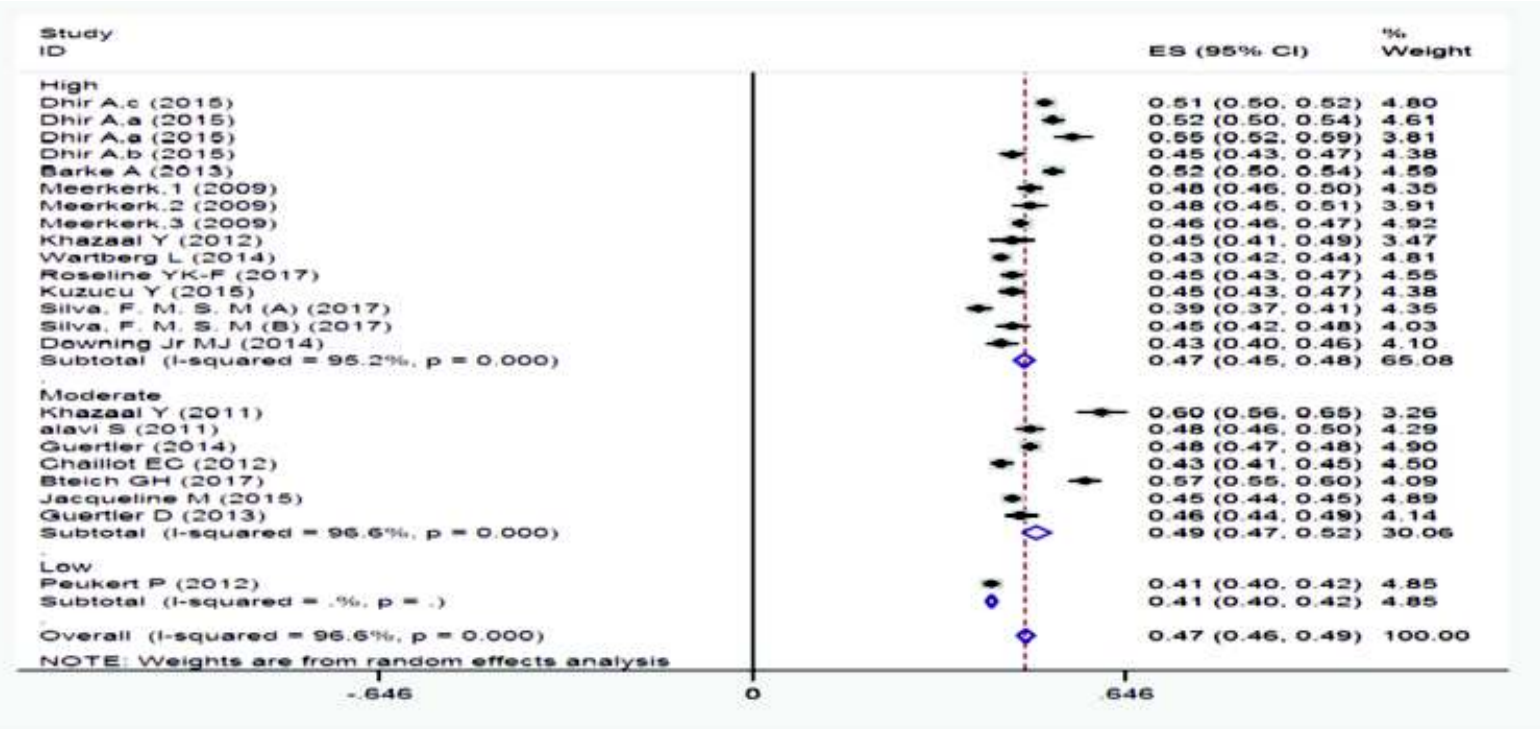

Figure 4. Forest plot of Cronbach's a for quality assessment of studies 


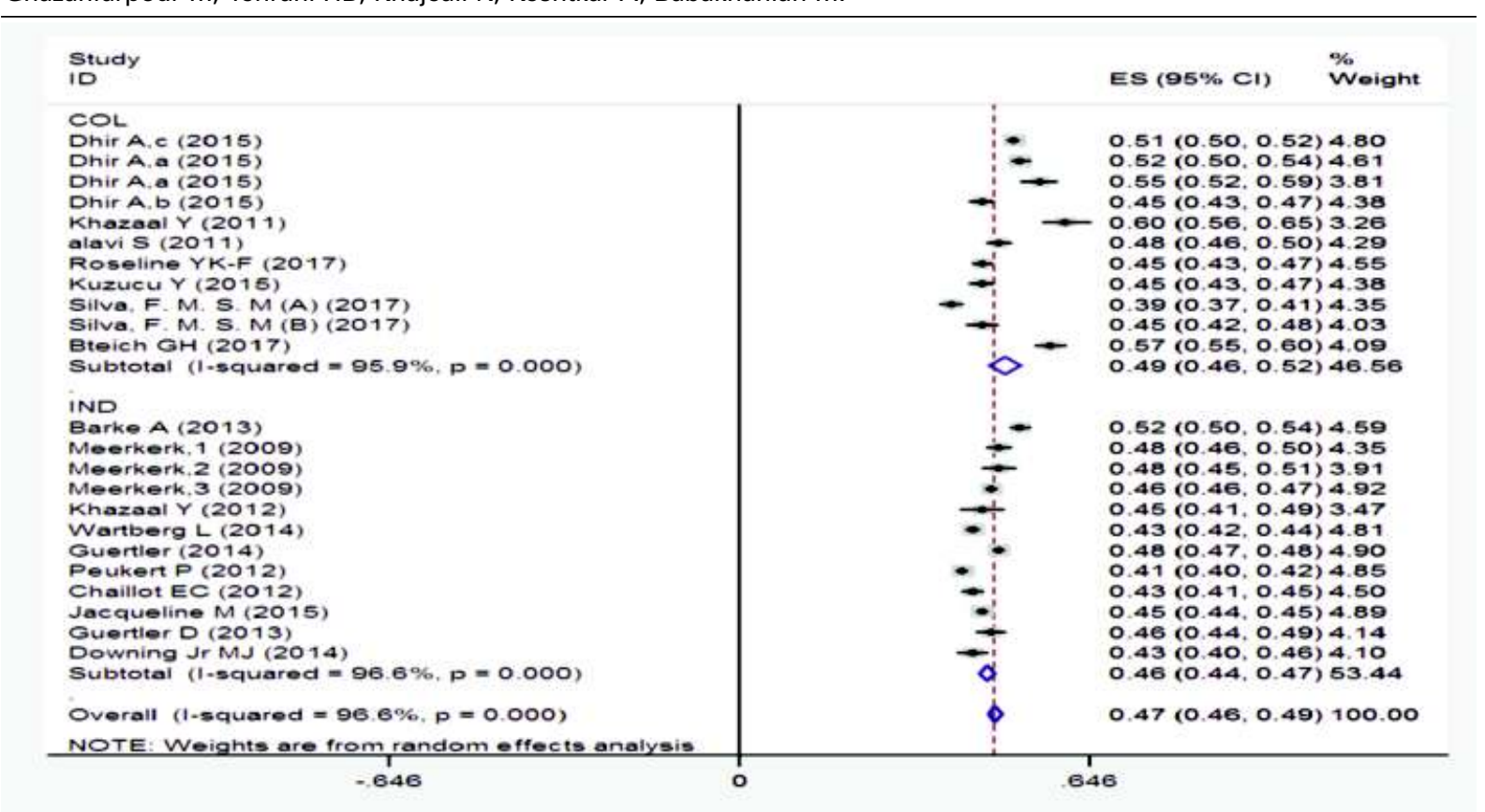

Figure 5. Forest plot of Cronbach's a for culture of countries

sample size is adequacy or not for example popular one method is Monte Carlo Basis of the rule of thumb (36). Based on the rule of thumb lit is highly suggested to have at least five cases for each item to conduct an exploratory factored analysis. Some studies did not enough sample size for study and internal consistency. Almost half of the study did not perform the test- retests carried out. As far as I know, there were not any studies to be conducted based on Item Response Theory, this important should be conducted in future studies. The postanalysis power through assessing the adequacy of the sample size was not assessed in any of the studies' limitations, missing percentage of items and how they were handled was not underlined in any of the studies. Also, they did not report KMO that was considered as an indication to assess the adequacy of sample size. Psychometric Properties of Compulsive Internet Use Scale (CIUS) were assessed in many countries, for example, Japanese, and German, Iran, etc. Future studies should assess the factorial structure in other communities.

\section{CONCLUSION}

Based on the current Evidence reliability of the questionnaire is adequate as a screening tool for assessing the Compulsive Internet Use with Cronbach alpha. However, future studies should be conducted on the multiethnic population and cross-cultural designee. Future studies should be developed and reported based on the COSMIN checklist.

Correspondence address: M.D. Masoudeh Babakhanian, Student Research Committee. Psychiatry and Behavioral Research Centre. Addiction Institute. Mazandaran University of Medical Sciences. Sari, Mazandaran, Iran babakhanian.m@gmail.com

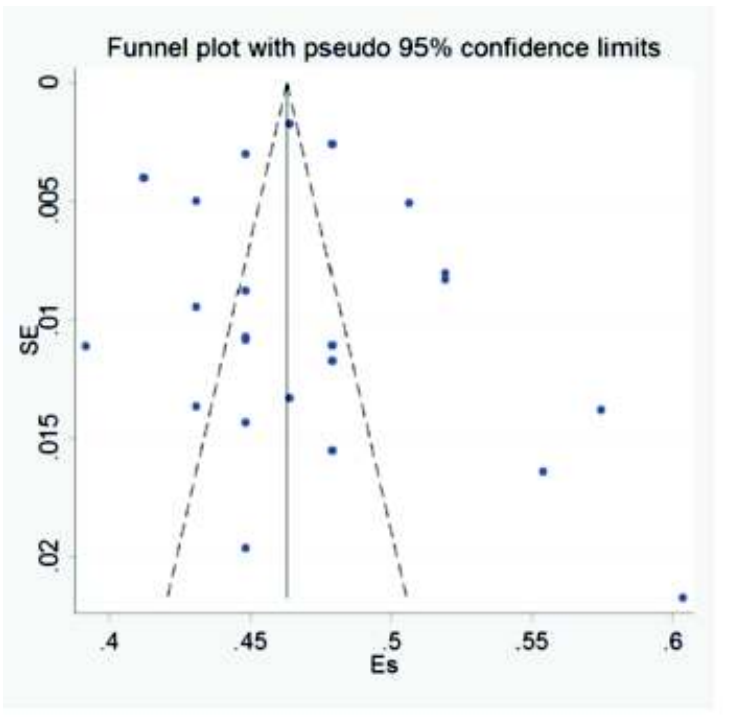

Figure 6. Funnel plot. 


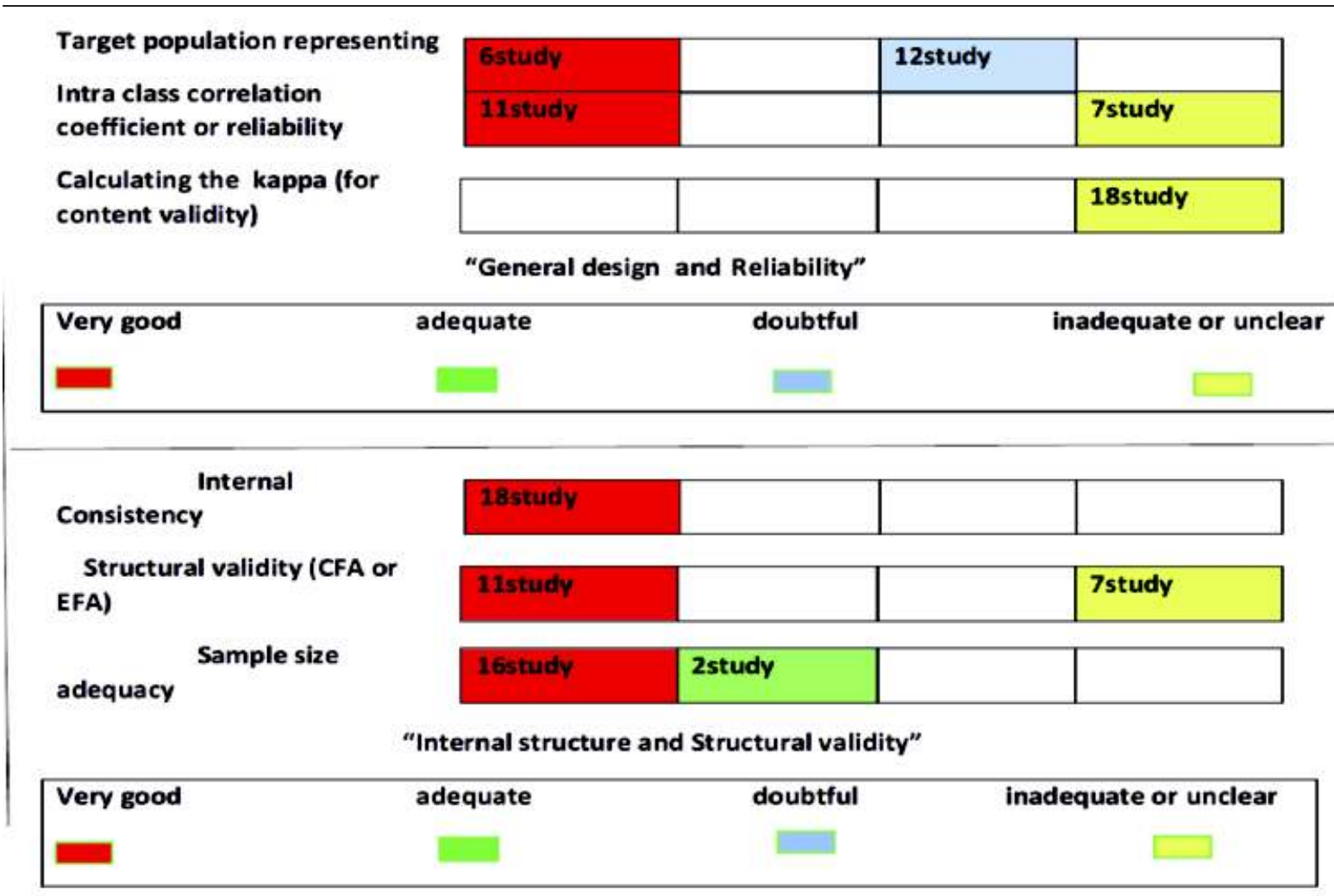

Figure 7. Assessment of the methodological quality of 18 studies by COSMIN Risk of Bias checklist for systematic reviews(16)

\section{REFERENCES}

1. Casaló LV, Escario J-J. Predictors of excessive internet use among adolescents in Spain: The relevance of the relationship between parents and their children. Computers in Human Behavior. 2019;92:344-51.

2. Young K. Internet addiction: diagnosis and treatment considerations. Journal of Contemporary Psychotherapy. 2009;39:2416.

3. Wiederhold BK. Stop scrolling, start living: The growing reality of internet addiction disorder. Mary Ann Liebert, Inc. 140 Huguenot Street, 3rd Floor New Rochelle, NY 10801 USA; 2018.

4. Grant JE, Potenza MN, Weinstein A, Gorelick DA. Introduction to behavioral addictions. The American journal of drug and alcohol abuse. 2010;36:233-41.

5. Durkee T, Carli V, Floderus B, Wasserman C, Sarchiapone M, Apter A, et al. Pathological internet use and risk-behaviors among European adolescents. International Journal of Environmental Research and Public Health. 2016;13:294.

6. Brenner V. An initial report on the online assessment of Internet addiction: The first 30 days of the Internet usage survey,[cited 2009 May 29]. Avaiable from: URL: http://www ccsnet com/prep/pap/pap8b/638b/012p tx. 1996.

7. Young K. Internet addiction survey. Retrieved May. 1996;5:2006.

8. Chou C, Chou J, Tyan N-CN. An Exploratory Study of Internet Addiction, Usage and Communication Pleasure. 1998.
9. Meerkerk G-J, Van Den Eijnden RJ, Vermulst AA, Garretsen HF. The compulsive internet use scale (CIUS): some psychometric properties. Cyberpsychology \& behavior. 2009;12:1-6.

10. Mokkink L, Terwee C, Patrick D, Alonso J, Stratford P, Knol $\mathrm{D}$, et al. The COSMIN checklist manual. 2009. Amsterdam, Netherlands: VU University Medical Center. 2016.

11. Hofstede G. The interaction between national and organizational value systems [1]. Journal of management studies. 1985;22:347-57.

12. Rodriguez MC, Maeda Y. Meta-analysis of coefficient alpha. Psychological methods. 2006;11:306.

13. Card NA. Applied meta-analysis for social science research: Guilford Publications; 2015.

14. Higgins J, Green S. Cochrane Handbook for Systematic Reviews of Interventions Version 5.1. 0 [updated March 2011]. The Cochrane Collaboration, 2011. Available from www. cochrane-handbook. org. Accessed August. 2011;29.

15. Deeks JJ, Higgins JP, Altman DG. Analysing data and undertaking meta-analyses. Cochrane handbook for systematic reviews of interventions: Cochrane book series. 2008:243-96.

16. Tseng OL, Spinelli JJ, Gotay CC, Ho WY, McBride ML, Dawes MG. Promoting bone health management in women diagnosed with breast cancer: a pilot randomized controlled trial. Archives of Osteoporosis. 2018;13(1).

17. Alavi SS, Jannatifard F, Eslami M, Rezapour H. Survey on 
validity and reliability of diagnostic questionnaire of internet addiction disorder in students users. Zahedan Journal of Research in Medical Sciences. 2011;13:34-8.

18. Downing Jr MJ, Antebi N, Schrimshaw EW. Compulsive use of Internet-based sexually explicit media: Adaptation and validation of the Compulsive Internet Use Scale (CIUS). Addictive Behaviors. 2014;39:1126-30.

19. Wartberg L, Petersen K-U, Kammerl R, Rosenkranz M, Thomasius R. Psychometric validation of a German version of the compulsive Internet use scale. Cyberpsychology, Behavior, and Social Networking. 2014;17:99-103.

20. Guertler D, Broda A, Bischof A, Kastirke N, Meerkerk G-J, John U, et al. Factor structure of the compulsive internet use scale. Cyberpsychology, Behavior, and Social Networking. 2014;17:46-51

21. Guertler D, Rumpf H-J, Bischof A, Kastirke N, Petersen $\mathrm{KU}$, John U, et al. Assessment of problematic internet use by the compulsive internet use scale and the internet addiction test: A sample of problematic and pathological gamblers. European Addiction Research. 2014;20:75-81.

22. Peukert P, Steffen S, ElKasmi J, Barth GM, Meerkerk G-J, Batra A. Faktorielle Struktur der deutschen Version der Compulsive Internet Use Scale (CIUS) nach konfirmatorischer Faktorenanalyse. Zeitschrift für Klinische Psychologie und Psychotherapie. 2012.

23. Dhir A, Chen S, Nieminen M. A repeat cross-sectional analysis of the psychometric properties of the Compulsive Internet Use Scale (CIUS) with adolescents from public and private schools. Computers \& Education. 2015;86:172-81.

24. Dhir A, Chen S, Nieminen M. Psychometric validation of the Chinese compulsive internet use scale (CIUS) with Taiwanese high school adolescents. Psychiatric Quarterly. 2015;86(4):58196.

25. Khazaal Y, Chatton A, Atwi K, Zullino D, Khan R, Billieux J. Arabic validation of the compulsive internet use scale (CIUS). Substance abuse treatment, prevention, and policy. 2011;6:32.

26. Khazaal Y, Chatton A, Horn A, Achab S, Thorens G, Zullino D, et al. French validation of the compulsive internet use scale (CIUS). Psychiatric Quarterly. 2012;83:397-405.

27. Kuzucu Y, Ozdemir Y, Ak S. Psychometric properties of a Turkish version of the compulsive internet use scale. European Scientific Journal, ESJ. 2015;11(1).

28. Sales HFS, de Jesus Lopes B. Adaptação da escala de uso compulsivo de Internet para avaliar dependência de smartphone. Avances en psicología latinoamericana. 2018;36:155-66.

29. Yong RKF, Inoue A, Kawakami N. The validity and psychometric properties of the Japanese version of the Compulsive Internet Use Scale (CIUS). BMC psychiatry. 2017;17:201.

30. Bteich G, Berbiche D, Khazaal Y. Validation of the short Arabic UPPS-P impulsive behavior scale. BMC Psychiatry. 2017;17:244.

31. Chaillot EC, Ingason H. Internetnotkun meğal háskólanema. Şı̆̆ing og forprófun á Compulsive Internet Use Scale (CIUS).

32. Nyenhuis N, Barke A. The Compulsive Internet Use Scale
(CIUS) adapted to assess excessive multiplayer gaming. Journal of Addiction Research \& Therapy. 2013;4(05).

33. Vink JM, van Beijsterveldt TC, Huppertz C, Bartels M, Boomsma DI. Heritability of compulsive I nternet use in adolescents. Addiction biology. 2016;21(2):460-8.

34. Podsakoff P, MacKenzie S, Lee J, et al. Common method biases in behavioral research: a critical review of the literature and recommended remedies. J Appl Psychol. 2003; 88:879-903.

35. Özlem Hekim, Zeynep Goker, Hilal Aydemir, Esra Çöp, Gülser Dinç, Özden Üneri. Internet addiction and its relation with psychopathology in adolescents: A cross-sectional study (tur). T J Clin Psy. 2019; 22:329-337

36. Najjari F AM. Deaths Due to Poisoning Referred to Legal Medicine Organization of Iran. RJMS. 2004;11:309-16. 